\title{
UM LUGAR MAIS ORIGINÁRIO QUE O ESPAÇO: JOSELY VIANNA BAPTISTA E LUCRECIA MARTEL
}

\author{
A MORE ORIGINAL PLACE THAN THE SPACE: \\ Josely Vianna Baptista and LUCRECIA MARTEl
}

Susana Scramim

ORCID: 0000-0002-0316-0582

Universidade Federal de Santa Catarina

Florianópolis, SC, Brasil

\section{Resumo}

Nas histórias literárias do Ocidente, a ideia de natureza foi vinculada ao problema do pertencimento. As questôes relativas ao espaço originário se desdobram em outras demandas para a crítica literária. Em gestos que tentam encenar questóes do pertencimento-náo pertencimento ao espaço, os trabalhos de Josely Vianna Baptista e Lucrecia Martel estabelecem "lugares" para "situar" as relaçóes entre voz e linguagem/ natureza e escrita. Seus efeitos são esvaziados de finalidade e, com isso, deixam ver uma segunda natureza dependente de um novo tipo de copertencimento dado por novas relaçôes ontológicas derivadas de outros usos do ato de nomear. O objetivo deste estudo é analisar os modos pelos quais essa disposição se materializa no poema-vídeo Nada está fora do lugar de Josely V. Baptista e no longa-metragem Zama de Lucrecia Martel.

Palavras-chave: Josely Vianna Baptista, Lucrecia Martel, subjetividade e arte latinoamericanas, poesia, cinema.

\section{Abstract}

In Western literary histories, the notion of nature was linked to the issue of belonging. Questions related to the original space unfold in other demands for literary criticism. In gestures that try to enact issues of belonging/not belonging to space, the works of Josely Vianna Baptista and Lucrecia Martel establish "places" to "situate" the relationships between voice and language / nature and writing. Their effects are devoid of purpose and thus they reveal a second

\section{Resumen}

En las historias literarias de Occidente, la idea de naturaleza fue vinculada al problema de la pertenencia. Las cuestiones relacionadas con el espacio original se despliegan en otras demandas para la crítica literaria. En gestos que intentan representar cuestiones de pertenencia-no pertenencia al espacio, las obras de Josely Vianna Baptista y Lucrecia Martel establecen "lugares" para "situar" las relaciones entre voz y lenguaje / naturaleza y escritura. Sus efectos carecen 
nature that depends on a new type of co-registration, which is the result of new ontological relations derived from other uses of the act of naming. The aim of this study is to analyze the ways in which this disposition materializes in the video poem Nothing is out of place by Josely V. Baptista and in the feature film Zama by Lucrecia Martel.

Keywords: Josely Vianna Baptista, Lucrecia Martel, Latin American art and subjectivity, poetry, cinema. de finalidad y, con ello, dejan ver una segunda naturaleza dependiente de un nuevo tipo de copertenencia dado por nuevas relaciones ontológicas derivadas de otros usos del acto de nombrar. El objetivo de este estudio es analizar las formas en que esta disposición se materializa en el video poema Nada está fuera de lugar para Josely V. Baptista y en el largometraje Zama de Lucrecia Martel.

Palabras clave: Josely Vianna Baptista, Lucrecia Martel, arte y subjetividad latinoamericanos, poesía, cine.

There is no utopy like a place There is no place like a utopy Lenora de Barros (1994)

O trabalho poético de Josely Vianna-Baptista com a linguagem verbal envolve plasticidade na sua trama, permitindo ao leitor e à autora fazerem correlaçóes com seus trabalhos visuais e sonoros e com os de outros autores. Destaco nesta análise três poemas escritos em diferentes momentos da trajetória de Josely: "Outro" (2001), escrito juntamente com Arnaldo Antunes, "sue", incluído em Roça Barroca (2011), e Nada está fora do lugar, publicado em 2017 sob a forma de plaquette. Correlaciono esses poemas ao poema-vídeo Nada está fora do lugar, também publicado em 2017, porque compreendo que a sonoridade engendrada na linguagem própria de cada um desses poemas - suas ressonâncias externas e assonâncias internas - permitiram à autora, juntamente com a potência das imagens criadas pelos seus versos, o diálogo com a linguagem cinematográfica, resultando na criação do poema-vídeo. Os três poemas de Josely Vianna Baptista a que me refiro nesta análise já possuem internamente as imagens e os sons que serão recuperados e "transcriados" em outras imagens e sons nos fotogramas do poema-vídeo Nada está fora do lugar.

A partir desse procedimento comparativo entre materialidades distintas nas composiçóes de Josely Vianna Baptista, correlaciono os poemas da poeta paranaense ao filme Zama (2017), dirigido por Lucrecia Martel ${ }^{1}$.

1 Lucrecia Martel é uma cineasta argentina. Suas obras tratam da decadência burguesa, especialmente aquela vivida pelas sociedades periféricas no interior das províncias no norte da Argentina. Seus filmes podem ser considerados como trabalhos de resistência ao mundo massificado. O espectador de seus filmes 
Trata-se de uma adaptaçáo cinematográfica do romance Zama² (1956) de Antonio Di Benedetto 3 . Compreenderei o filme de Lucrecia Martel como um "desdobramento" ${ }^{4}$ do texto de Di Benedetto. E tomarei o processo de construção e montagem das imagens de Martel como um processo de tornar mais complexa a tarefa de refletir sobre o mundo latino-americano empenhada pela escrita do romance de Di Benedetto. Essa disposição do cinema de Martel é, em minha análise, associada àquela dos que exercem a atividade da escrita na América Latina, pensada como um lugar discursivo, e inserida na dialética negativa entre o "Dizer" e o "Ser", bem como formadora de subjetivaçóes que equacionam uma concepção, contraditória em seu funcionamento, de identidade coletiva. O espaço geopolítico onde os trabalhos de Josely e Lucrecia se situam será tomado nesta análise como o "teor" da experiência latino-americana na modernidade, "lugar" de uma experiência autêntica.

Além de correlacionar os poemas analisados neste ensaio aos "redobramentos" internos de sua produção criativa, compreenderei $\mathrm{Nada}$

é exigido corporalmente durante a relação com a obra, pois se cobra atenção redobrada aos detalhes mais ínfimos nas cenas, porque estáo carregados de potência de sentido. Seus filmes mais conhecidos sấo: Rey muerto (1995), La ciénaga (2001), La niña santa (2004), La mujer sin cabeza (2008), Pescados (2010), Muta (2011), Leguas (2015), El aula vacía (2015), Zama (2017), AI (2019).

$2 \mathrm{O}$ romance Zama do escritor argentino Antonio Di Benedetto trata da relaçáo de um sujeito situado em uma sociedade periférica na empresa da colonização espanhola no Cone Sul. A ambientaçáo espacial da narrativa é repleta de sentidos para a construçáo da experiência do personagem principal Don Diego de Zama. O local em que se passa a história é, provavelmente a cidade de Asunción, distante do centro do poder da capital do Virreinato del Río de la Plata, que era Buenos Aires, e, portanto, situado à margem do mundo cultural e simbólico da colônia, apartado do poder econômico e cultural de sua própria sociedade. A narrativa dessa experiência acontece a partir da imagem que se constrói do sujeito - que é um alto funcionário a serviço da coroa espanhola - confrontado com uma situaçáo de espera para o regresso ao centro, pelo menos, do centro da periferia colonial cisplatina, Buenos Aires. Sua condiçâo subjetiva está marcada por essa geopolítica, e não encontra ressonâncias identitárias com a região onde vive, apenas dissonâncias.

3 Antonio Di Benedetto, nascido em 1922, na cidade de Mendoza, na Argentina, não é um autor especialmente conhecido no Brasil. Coincidiu com o boom da literatura latino-americana, mas não esteve entre seus principais autores. Décadas depois do boom, ele foi reivindicado por Roberto Bolaño e Juan José Saer, que o definiram como autor de uma obra que não teve precursores argentinos. Publicou Zama em 1956, que é o primeiro livro de uma série denominada "trilogia da espera", e foi seguido por El silenciero (1964) e Los suicidas (1969), que possuem personagens, sagas, dramas e épocas distintos entre si, mas que compartilham o conflito interno da crise de identidade até o ponto de chegarem à alienação total ao serem confrontados com situaçóes de espera que estão relacionadas a diferentes acontecimentos nos romances.

4 Me refiro, com o termo "desdobramento", à "dobra", conceito de uma ontologia do possível, "le pli" de Gilles Deleuze, desenvolvido a partir da sua leitura da obra de Leibniz. As dobras internas nesse conceito sáo compreendidas como forças de ação e, portanto, de existência que estão contidas originalmente nos núcleos da matéria exposta no mundo. Trata-se de um "redobramento" do exterior que tem potência de gerar singularidades desdobradas a partir dessa exposição no mundo. A reflexão de Lezama Lima sobre o Barroco Americano envolve também essa ideia de que a matéria em exposição no mundo - quando do encontro entre as civilizaçóes americanas e europeias - dá a ver a dimensão complexa e dialética entre o exterior e o interior. O neobarroco americano entenderá que a "dobra" do exterior no processo de colonização vem revelar uma terceira dimensão da não-relaçấo entre o dizer e o ser, que está em consonância com a relação entre conhecimento e poder. É a dimensão da subjetivação, a dimensão de si do latino-americano. 
está fora do lugar de Josely - na sua comparaçáo com Zama de Martel - como pertencente a um lugar discursivo: a arte latino-americana e o fluxo ocidental da qual forma parte e, ao mesmo tempo, da qual é excluída. Para indicar o lugar da formaçáo do discurso latino-americano como um lugar sem lugar - sendo, assim, como discursividade que prenuncia o sujeito - interessa sobremaneira a esta análise o espaço geográfico onde está ambientado o poema-vídeo de Josely, bem como o espaço onde se desenvolve o romance de Di Benedetto e o filme de Lucrecia Martel. Nesses trabalhos, o espaço geopolítico está bastante correlacionado ao discurso com o qual se elaboram as subjetividades latino-americanas. Ali os extremos se tocam: o exterior e o interior. Nesse espaço há necessidade de mediação e ela gera traumas, justamente em função das contradiçóes do contato entre extremos. No espaço latino-americano extremadamente conflituoso, o empreendimento colonial age no sentido da internalização da alteridade para o âmago do Eu colonial e, no lugar da consideraçáo da alteridade local, faz surgir uma subjetividade capturada pelo discurso autorreprodutor da exploração colonial. De muitas maneiras, o discurso sobre a subjetividade replica - frequentemente de modo acrítico - essa contradição.

Os dois trabalhos de Josely e Lucrecia se instalam em uma geografia conflituosa, o Chaco. Tanto a regiáo do Guairá quanto as margens do rio Paraguai na região de Asunción estão compreendidas em uma imensa planície, que vem - pelo seu lado leste - precedida por um grande planalto, o que já é, em si, um valor de distinção hierárquica: o planalto contém ar mais elevado e puro se comparado ao "bafo úmido" da depressão nas planícies. A comparação entre seus trabalhos artísticos demonstrará o quanto o ambiente dessa vasta planície está bastante relacionado a seus produtos culturais, e fará ver que a relação entre ambiente, linguagem e "humanidade" deve ser considerada no processo de compreensão desses "lugares" a que chamamos de Argentina, Bolívia, Brasil, Paraguai.

Começarei pela comparação entre os poemas de Josely, aos quais me referirei como sendo "versôes". As diferentes formas acabadas e publicadas desses poemas serão analisadas no conjunto do extenso poema "Nada está fora do lugar". Esses poemas serão tratados a partir do pressuposto de que contêm uma "forma interna" que se vai desdobrando em outras formas. E, a partir delas, "Nada está fora do lugar" lentamente formula um pensamento do lugar da poesia na América Latina em diferentes âmbitos dentro de sua própria obra.

Associado ao conceito de "dobra" - que prevê a proliferação infinita das singularidades no contexto de um caos-cosmo -, retomo, para analisar o reaparecimento de poemas de Josely Vianna Baptista no âmbito de sua própria obra, o conceito de "versóes" da análise que Walter Benjamin fez 
de dois poemas de Hölderlin, estendendo-o para uma consideração geral da escrita da poesia na modernidade. Entre os anos de 1914 e 1915, o filósofo se dedicava a questionar na obra de Kant o que julgava uma idealização do pensamento iluminista por parte do racionalismo individualista. Benjamin contrapóe ao racionalismo da suposta separação entre forma e conteúdo a ideia de uma linguagem pensada mediante seu "teor" (Gehalt). O conceito foi tomado por Benjamin a partir de Goethe, que pretendia proporcionar através do tratamento do signo verbal uma experiência orgânica entre o sujeito da criação e o mundo 5 . A experiência linguística, nesse sentido, era criada a partir da consideração dos processos de escrita que, sem se isolar na observação de seus procedimentos imanentes, abria-se à observaçáo do pertencimento de sua linguagem ao conjunto da natureza. Benjamin encontrou na poesia de Hölderlin essa potência em conferir "teor" à experiência artística. $\mathrm{O}$ poeta abandona, segundo Benjamin, a ideia da força criativa do indivíduo e a canaliza para a observaçáo do fluxo da linguagem em seus processos de nomeaçáo em consonância com a crítica aos processos de classificação e hierarquização das coisas no mundo. Benjamin considera como a "tarefa" da poesia trazer à superfície da linguagem o resultado dessa experiência. Ao analisar dois poemas de Hölderlin, tratando-os como versões de um mesmo ato criativo-reflexivo - "Coragem do poeta" (Dichtermut) e "Timidez" (Blödigkeite) -, Benjamin condicionou o cumprimento dessa tarefa poética para a avaliação de qualquer poema. Tratou o processo de escrita desses poemas como "metamorfose" da obra dentro de si mesma na sua relação com o mundo. Segundo esse critério de análise, o valor de um poema não se encontra na avaliação dos modos utilizados pelo poeta para resolver sua tarefa; ao contrário, é a seriedade e a grandeza da tarefa mesma que irão determinar esse julgamento de valor. Benjamin continua: "Pois essa tarefa é derivada do próprio poema. Ela há de ser entendida também como condição da poesia, como a estrutura intelectualintuitiva daquele mundo de que o poema dá testemunho" (BENJAMIN, 2011, p. 14).

5 A relação que Goethe encontra - e a obsessão que Walter Benjamin redobra a partir de sua obra - entre linguagem e mundo pode ser observada em diversos trabalhos seus. Faço um pequeno destaque da citação de Benjamin, como epígrafe ao capítulo introdutório "Questôes introdutórias de crítica do conhecimento" do Origem do drama barroco alemão, do estudo de Goethe sobre as cores. "Posto que nem no saber, nem na reflexão podemos chegar ao todo, já que falta, ao primeiro, a dimensão interna e, à segunda, a dimensão externa, devemos ver na ciência uma arte, se esperamos dela alguma forma de totalidade. Náo devemos procurar essa totalidade no universal, no excessivo, pois assim como a arte se manifesta sempre, como um todo, em cada obra individual, assim a ciência deveria manifestar-se, sempre, em cada objeto estudado". (GOETHE apud BENJAMIN, 1984, p. 49). 
Espaço em movimento: uma teoria do lugar

Poema de Josely Vianna Baptista, publicado em 2017 pela editora paulistana Demônio Negro, Fábula NADA ESTÁ FORA DO LUGAR poema arborescente ${ }^{6}$ foi apresentado e introduzido na edição por dois textos do artista visual Francisco Faria. Trata-se de uma plaquette, detentora do sentido de ser uma publicação à parte, separada e ao mesmo tempo incluída em um "todo" que inclui várias versóes do poema em diferentes línguas. Causa estranhamento o fato de tamanha diversidade de registros do poema ser fruto de desdobramentos internos de seus processos de criação.

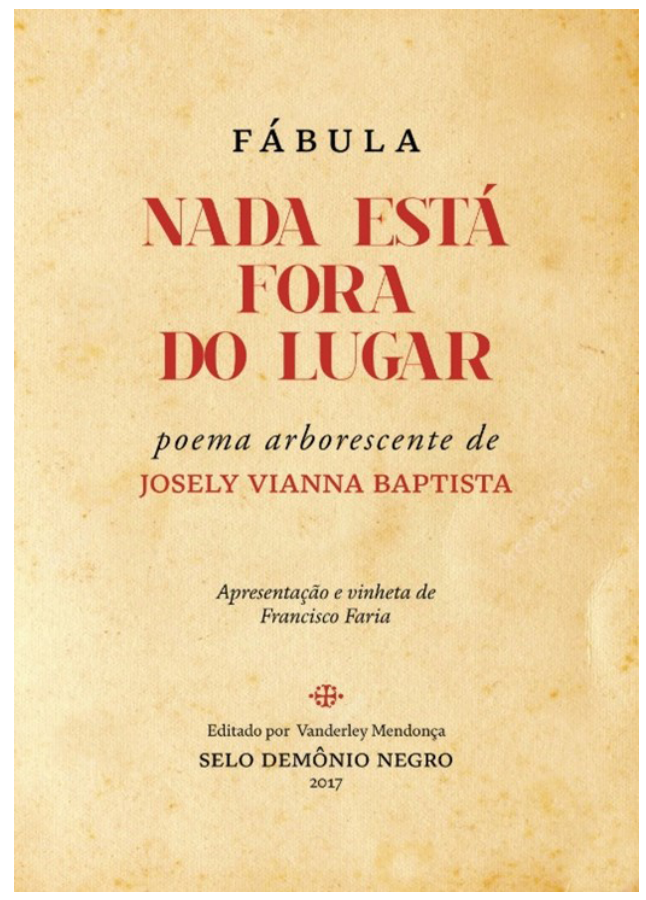

Antes da separata final e assunção do poema em vídeo, Josely, juntamente com Arnaldo Antunes, em 2001, compóe um poema intitulado "Outro", que foi recuperado em partes no âmago do poema-fábula Nada está fora do lugar. O poema "Outro" se desdobrou em 2011, no livro Roça Barroca, na série que fecha o livro, no poema "sue". Ali, em Roça Barroca, Josely recupera com "sue" uma das vozes do poema "Outro". Em outro lugar, no ano de 2015, em seu projeto $\mathrm{Na}$ tela rútila das pálpebras talvez se encontre a "versão" mais próxima do que será o "poemafábula" Nada está fora do lugar - esse e canto-

6 A ediçấo do poema possui um nível de detalhamento apenas comparado a ediçốes para colecionadores: em risografia em 2 cores, sobre papel Polén Bold 90g, tiragem de cem exemplares numerados. 
conto "polilíngue" produtor de experiência intersubjetiva - com as remissóes aos dois poemas referidos anteriormente ${ }^{7}$.

No ano de 2017, aparece o poema-vídeo de Josely Vianna Baptista, Nada está fora do lugar, que foi exibido na Festa Literária de Paraty. Tratase de criação coletiva de Josely, Yasmin Thayná, Waltel Branco, Guillermo Sequera e Francisco Faria. Segundo o texto de apresentação do poema-vídeo, o trabalho foi inspirado nas migraçóes proféticas em busca da "Terra sem Mal" ("yvy marẩey") e pontuado pela menção - em "Coix lacryma" - ao etnocídio dos Guaranis. O poema-vídeo ainda traz um eco da reciprocidade do "jopói" guarani, as mãos abertas que doam, apresentando-nos uma natureza no limiar da cultura ${ }^{8}$.

O trabalho que resultou no poema-vídeo reuniu a tradução em três línguas de fragmentos de "versôes" - no sentido de Benjamin ao analisar os poemas de Hölderlin - dos poemas "Outro", "sue" e "Nada está fora do lugar" de $\mathrm{Na}$ tela rútila das pálpebras, os quais fizeram parte da composição do livro Fábula NADA ESTÁ FORA DO LUGAR que Josely publicou em 2017. No vídeo consta a enunciação de diferentes vozes de poetas e líderes comunitários indígenas que leem os versos de Josely, e que são entrecortadas por sons do mundo exterior. Esse mundo exterior é tomado no contexto da prática discursiva latino-americana que tem como fundamento a íntima experiência - originária e desestabilizadora - com as línguas, com a natureza selvagem, suas águas, matas, florestas, geologia. Os sons originados nesse espaço geográfico aparecem na sequência das imagens e entre as vozes que enunciam os poemas com o objetivo de não serem registrados meramente para serem ouvidos como reproduçóes da exterioridade do mundo, e sim localizados na relação entre essas experiências sensoriais. Os sons dos animais parecem ser muito próximos da realidade; contudo, soam estranhos uma vez que há certa repetição e frequência hiperbólica da sequência dos ruídos, como, por exemplo, na sequência em que os sons dos sapos são "confundidos" com instrumentos de percussão, compondo com os versos um ritmo interligado, uma vez que são lidos na mesma sequência, produzindo metamorfoses e, principalmente, introspecção sonora para aquilo - o exterior - que está ao redor do texto verbal e que náo tem voz. A existência de uma "subjetividade

7 Na tela rútila das pálpebras foi uma publicação digital que traçou um panorama da história e das paisagens dos Campos Gerais do Paraná. No formato de uma revista eletrônica, textos históricos e literários, ensaios fotográficos, desenhos e arte digital se alternam e se combinam.

8 Esse projeto é transdisciplinar e plurilíngue e reuniu a poesia de Josely Vianna Baptista, a pintura de Francisco Faria com a videoarte de Yasmin Thayná e a música de Waltel Branco. O trabalho etnográfico de Mirto Sequera e a organização musical de Pedro Jerônimo Vaz de Faria e Kito Pereira estimulam o contato da poesia com as ciências humanas. As traduçôes e leituras foram realizadas por Chris Daniels (inglês), Bogado Cristino (guarani) e Reynaldo Jiménez (espanhol), além de sua própria voz e da voz daxamã Nãnde Chy, Ceferina Martínez, e do pajé Ramói Guazu. 
discursiva" se situa nessa experiência sensorial diversa de se colocar na relação entre diferentes textualidades, o som dos fonemas sobreposto aos sons do ambiente (Figura 1). Nesse sentido, a experiência com a ideia de América Latina se organiza mediante a formação de intersubjetividades não hierárquicas, isto é, a consciência individual subjetiva não é o ponto de onde parte o olhar, ela apenas faz parte dele.

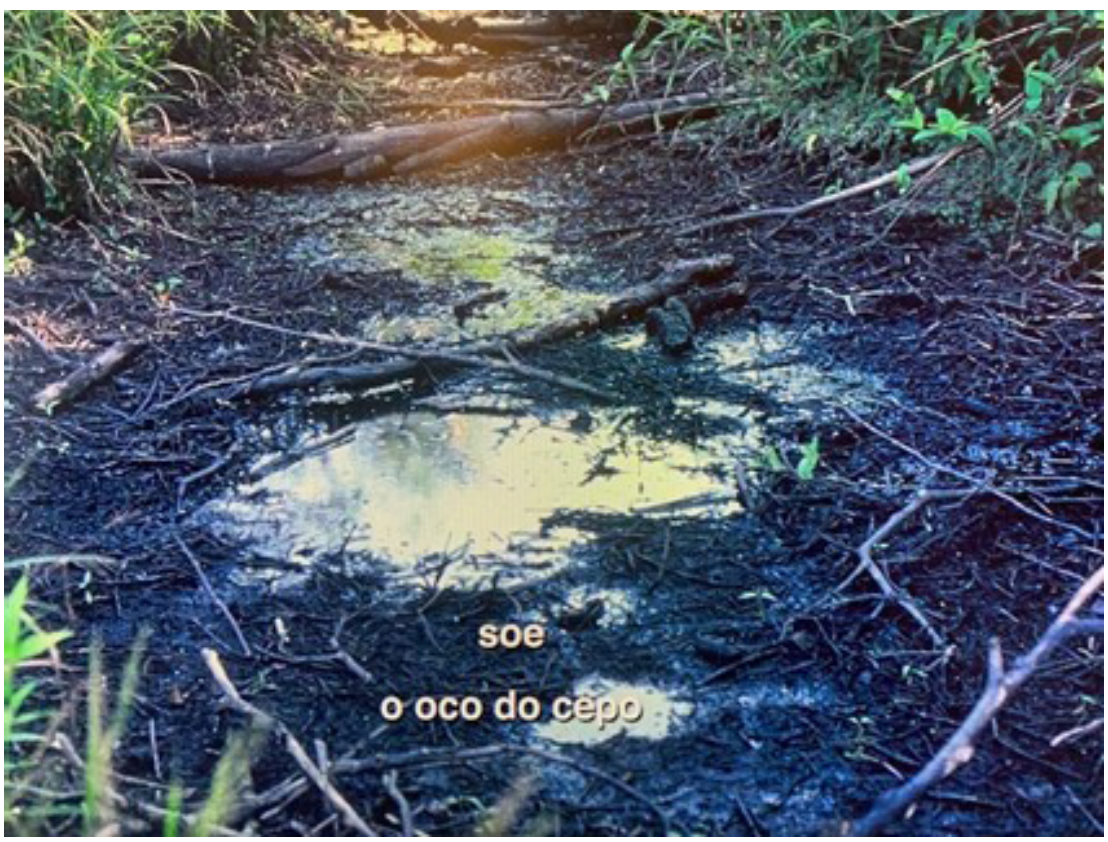

Figura 1 - Cena do "poema-vídeo" Nada está fora do lugar

Celia Pedrosa, em "Josely Vianna Baptista: uma poética xamânica da tradução e tradiçáo", compreendeu o trabalho da poeta paranaense como proposiçáo simultânea da experiência com o comum e o estranho, o que para Pedrosa envolveria uma noção de "experiência do intraduzível". A relação destacada em sua análise, além daquela do trânsito entre o verbal e o visual, é a da "articulaçáo" entre "materialidade da letra" e "imagens do corpo, da terra e do território" (PEDROSA, 2018, p. 7). Se comparada aos filmes de Lucrecia Martel - os quais dão conta dessa mesma articulação e trânsito entre as "imagens do corpo, da terra e do território" -, compreendo a poesia de Josely como articulação da imagem-experiência da linguagem com as do corpo e do ambiente, tentando dar conta de uma experiência intersubjetiva do sentir-se fora, estando em seu próprio lugar. Essa experiência do deslocamento constitui o discurso do protagonista no filme Zama, dirigido por Lucrecia 
Martel. Uma das cenas que dá testemunho dessa experiência é a alegoria dos peixes que se protegem entre as margens do rio para não serem lançados para fora de seu mundo e morrerem. A cena, que aparece logo no início da narrativa de Di Benedetto, no filme de Lucrecia é composta por uma certa "dança pela sobrevivência" de peixes submersos nas águas rasas e barrentas de um rio, funcionando como alegoria hiperbólica da experiência a que Diego de Zama dá vazão: um homem, agente do colonialismo na América Latina, um corregedor, que necessita se misturar às forças locais que persegue e explora para poder sobreviver; quando percebe que a empresa colonial pela qual se empenha o descarta, desobedece e tenta, mediante uma viagem individual, escapar do mundo do qual já faz parte. A essa alegoria composta por Di Benedetto - a do espaço habitável na colônia ser a experiência do sentir-se fora "do lar" - as imagens de Lucrecia Martel oferecem materialidade visual. A interioridade da "dobra" é produzida mediante a abertura à exterioridade. No romance de Di Bendetto, o personagem Ventura Prieto conta a Diego de Zama a "história" de um peixe que é rejeitado pelas águas do rio.

Disse que há um peixe, nesse mesmo rio, que as águas não querem e ele, $\mathrm{o}$ peixe, deve passar a vida, a vida toda, como o macaco, em vaivém dentro delas; de um modo ainda mais penoso, porque está vivo e tem de lutar constantemente com o fluxo líquido que quer arremessá-lo à terra. Disse Ventura Prieto que estes sofridos peixes, táo apegados ao elemento que os repele, talvez apegados apesar de si mesmos, têm de empregar quase que integralmente suas energias na conquista da permanência e, embora sempre estejam sob o perigo de serem arremessados do seio do rio, tanto que nunca são encontrados na parte central do leito, mas nas margens, alcançam vida longa, maior do que a normal entre os outros peixes. Só sucumbem, disse também, quando o seu empenho lhes exige demais e eles não podem campear alimento.' (DI BENEDETTO, 2006, p. 14).

Diego de Zama imediatamente se reconhece na história que Ventura Prieto lhe conta. No entanto, prefere não exteriorizar ao seu interlocutor o que a imagem lhe fez compreender, e recolhe-se em seu solilóquio (Figura 2), que, no filme de Lucrecia, é transformado em experiência sensorial de ver-

9 Dijo que hay un pez en ese mismo río, que las aguas no quieren y él, el pez, debe pasar la vida, toda la vida, como el mono, en vaivén dentro de ellas; pero de un modo más penoso, porque está vivo y tiene que luchar constantemente con el flujo líquido que quiere arrojarlo a tierra. Dijo Ventura Prieto que estos sufridos peces, tan apegados al elemento que los repele, quizás apegados a pesar de sí mismos, tienen que emplear casi íntegramente sus energías en la conquista de la permanencia y aunque siempre están en peligro de ser arrojados del seno del río, tanto que nunca se les encuentra en la parte central del cauce, sino en los bordes, alcanzan larga vida, mayor que la normal entre los otros peces. Sólo sucumben, dijo también, cuando su empeño les exige demasiado y no pueden procurarse alimento. (DI BENEDETTO, 2018, p. 25). 
ouvir o marulho provocado pela aflição dos peixes, já quase sem oxigênio, nas águas rasas do leito do rio. Nas imagens de Lucrecia, o ruído do parco fluxo de água produz a experiência com a angústia.

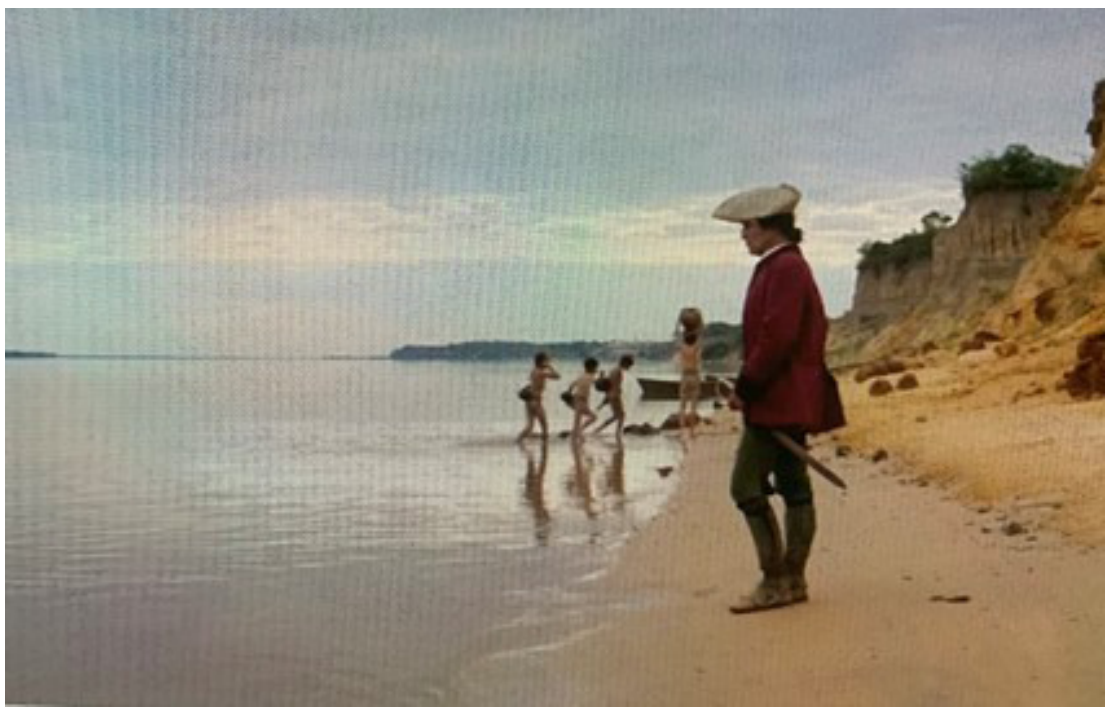

Figura 2 - Cena inicial do filme Zama (2017).

A prévia construção de sua identidade, do discurso de si, de seu cuidado e de seu reconhecimento próprio se transmutam em um contemplar sua existência a partir da exterioridade da vida daquele peixe que luta para não ser "expulso-morto" pela correnteza que domina do rio. Uma desconstrução de sua identidade começa a ser elaborada na experiência com os elementos que compóem seu habitat. Diego de Zama passa a ver a si mesmo através da melancolia resultante da rejeiçáo do seu referente. Diego de Zama, que se imaginava com uma identidade europeia, vai paulatinamente alterando a compreensão que tem de si mesmo, passando a entender-se como objeto a quem o europeu moderno explora na empreitada da colonização - como se fez com a natureza, o indígena, o africano, a mulher -. Essa alteração na imagem própria, permite ao personagem alcançar uma experiência autêntica de si. Por outro lado, esse reconhecimento não é dado a partir de uma representação "natural" do ambiente, há um acréscimo que transforma aquela natureza originária em algo bastante estranho. A busca do saber e do poder, que levará à deriva existencial de Diego de Zama culminando em não reconhecimento, é o ponto de partida dessa experiência. Entretanto, Diego de Zama não sabe ainda que o espaço latino-americano é, por excelência, um lugar de deslocamento de identidades que se compreendiam como próprias, 
mas que - no confronto entre si - descobrem que estáo todas sendo definidas incessantemente dentro de um mesmo lugar. Ainda que sejam completamente diferentes, apenas sobrevivem e se compreendem como sujeitos quando se entregam ao lugar. Não há nada mais realista e simultaneamente mais desrealizado do que a cena do filme (Figura 3) em que Zama espera pelo alimento que os índios lhe fornecem.

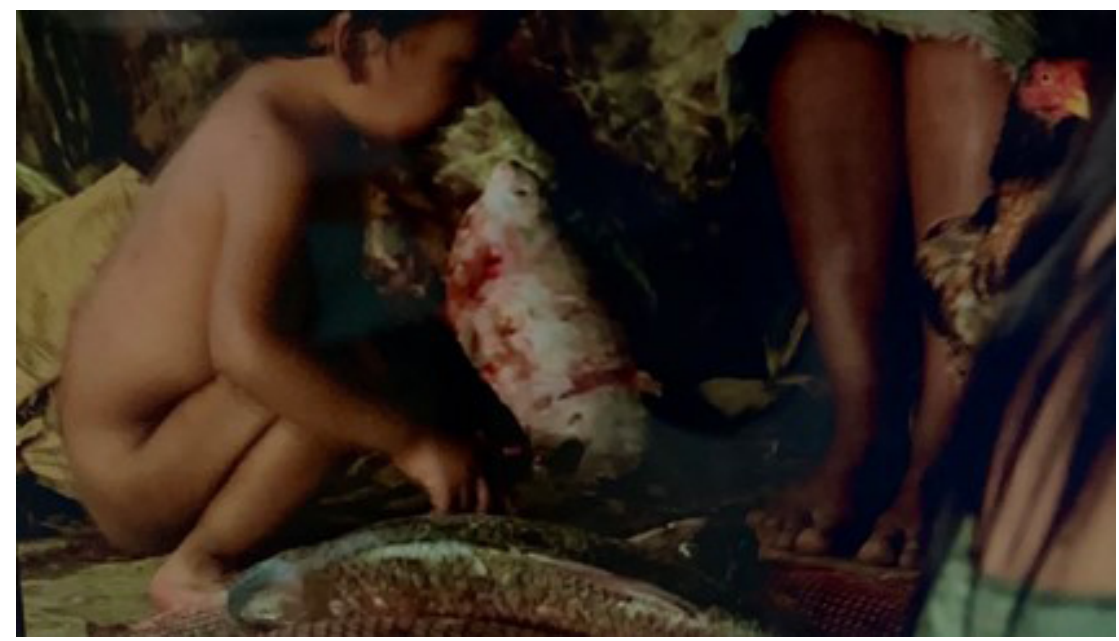

Figura 3 - Cena de Zama em que índios limpam o peixe para comer e fornecer alimento para os espanhóis.

A cena trata da presença do peixe do rio e da alteridade. $\mathrm{O}$ alimento (sustentáculo da reprodução vital) é fornecido pelo indígena (Outro não idealizado), o alimento é um peixe, o peixe é Zama que se debate para não ser expelido pelo caudal do rio, mas que foi capturado nele, justamente porque sua ação é em prol da repetição do modelo colonial. O problema do pertencimento (do lar) e do reconhecimento da família latino-americana e seu ambiente na formação do sujeito está entre as experiências fundamentais do trabalho poético desenvolvido por Josely Vianna Baptista. Celia Pedrosa já se propôs ler na poesia de Josely a articulação entre língua e imagem. A partir dessas conexóes entre corpo, terra e território já identificadas pela crítica carioca, gostaria de analisar alguns desses deslocamentos operados por Josely em trânsito para a arte. Sendo uma espécie de arquivo da experiência, o trabalho de Josely constrói uma memória de si, recolhe, seleciona e expóe as histórias que irão compor sua subjetividade, prática essa muito disseminada entre diferentes poetas atuantes na literatura brasileira atual. $\mathrm{O}$ arquivo de si inclui o trânsito entre memória sensorial individual e a coletiva e cultural que 
se trasvestem de linguagem articulada - trazendo consigo a memória formal da língua - como ponto de partida para a "desorganizaçáo" da hierarquia moderna que é apenas individual (SCRAMIM, 2007, p. 42).

No poema-vídeo Nada está fora do lugar, há estratos de texturas feitos com a matéria destruída da memória individual, cultural e natural. Não há o medo de ser expulso ou morto, já que o princípio de repetição não acontece com o intuito de reproduçáo de algum referente. Operando um movimento de "redobragem", o repertório poético recorre a esses mesmos estratos para se recompor e dar forma ao estranho, o Outro. A experiência do comum e a do estranho passam a ser elaboradas com um princípio de articulação entre essas experiências, capaz de produzir uma reflexão no leitor sobre a "artificialidade" do comum e a "naturalidade" do estranho, sempre tendo em vista a situação de "esvaziamento" do sentido único, uma vez que tanto a experiência do comum quanto a do estranho tomam forma no texto enquanto "cenas" de um grande teatro do mundo, pois a memória individual tem como cenário a natureza e a história. No entanto, o texto não caminha em direção à narratividade da história, seja ela a do eu que enuncia o discurso, seja a da história natural. Se há um gesto que tenta novamente encenar esses fatos sob o ponto de vista dos problemas do pertencimento-não-pertencimento, esse gesto se "erige" no contexto de um espaço naturalizado como familiar, nacional, comum, em que pese ser encarado em seu processo de desgaste, de corrosão e ressignificação.

O mesmo acontece com o discurso verbal que tece os fios do textopoema, ele se erige no "espaço" naturalizado do verso - a frase curta e a sintaxe recortada, constrita a esse espaçamento - que produz significação complexa. Era de se esperar que estivesse à vontade com a matéria familiar de que são feitas essas frases, compostas por palavras e sintaxe dessa língua materna do eu enunciativo: o português. Tudo isso seria facilitador e garantiria que o texto fosse acolhido pela comunidade que com ela - a língua - se identifica. Entretanto, a matéria dos fios é variada, são pelo menos quatro línguas as que se apresentam como as línguas da enunciação do texto no poema-vídeo: o português, o guarani, o castelhano e o inglês. $\mathrm{O}$ texto sai da zona de conforto da língua materna ao reivindicar diferentes línguas como meio de expressão verbal. Abandona a segurança do espaço geopolítico nacional-regional ao transbordar a fronteira política da regiáo provincial, ampliando-a para um limite gerado pelo mapa ambiental, pois nomeia os lugares com o designativo ligado ao seu uso no interior, passando, portanto, a denominá-la como Chaco, Guaíra e, no Na tela rútila das pálpebras, como "Campos Gerais", e não como o "segundo" e "terceiro" planaltos em contraste com a "baixada" da foz do rio Iguaçu. 
O texto de Nada está fora do lugar transita entre verso e prosa e também cruza novas fronteiras entre voz e linguagem, entre natureza e escrita, entre imagem e som, cujos efeitos são esvaziados de sua finalidade: o fim verso não produz familiaridade, a prosa não descreve a experiência com o estranho, a voz não fala de si, a linguagem não elabora, a natureza não é tomada como lugar de origem natural, a escrita não conta a história, a imagem não ilustra e o som não dá a ambiência. Com isso, o poema deixa ver uma segunda natureza que cria um novo tipo de pertencimento coletivo que não é mais aquele oferecido pelo princípio de identificação da natureza física com o lar que é o país e a língua, situando-se entre coisas diversas. Essa segunda natureza se deixa ver no trabalho árduo de perceber e flexionar os diferentes modos de usar os nomes. Por isso, o poema toma como sua tarefa o deslocamento textual entre zonas que superficialmente posicionam-se em oposição como, por exemplo, biologia e humanismo, o Eu e o Outro, o nacional e o estrangeiro, a fala articulada e o não-sentido. Tal posição não se situa em uma zona de conforto em direção ao valor absoluto: ao contrário, ela é zona de confronto sem trégua. Faz os corpos suarem no seu labor de produzir algo nessa linha de batalha. $\mathrm{O}$ poema "sue", publicado em Roça Barroca, dá testemunho dessa luta.

No poema "Outro", Josely Vianna Baptista e Arnaldo Antunes reconhecem que essa zona de criação está no espaço do confronto. O poema parte do reconhecimento de uma ressonância entre seres e lugares. Esse "agir" reconhecendo-se em sons vai se metamorfoseando na indicação dos efeitos do ato de reconhecer-se a si no próprio corpo. Vejamos algumas das vozes que lutam para produzir o "sujeito" entendido como um efeito de som no poema:

\author{
sou o que me soa \\ a sós se en \\ volvendo \\ sou o que me sua \\ em seda (falsa \\ transparência) \\ de sámara ao \\ vento \\ sentidos-indícios \\ fios de voz \\ silícios \\ nesse pó opaco \\ de cinzas \\ nenhum gesto \\ sem passado \\ nenhum rosto
}


sem o outro

no corpo:

rio correndo límpido

letras labaredas

signos votivos para sim e

silêncio

descompassado

entre boca e ouvido

perda

velando a si

mesmos

sou o que me soa

no próprio

sossego

essa e outra pessoa

sentidos adentro

sou o que me sua

de frutos

ressecos

abrindo seus velos

entre minha e tua

a um toque

dos dedos

moventes

secretos alados

sem centro

envoltos

(BAPTISTA; ANTUNES; BISCAIA 2001, p. 28)

O reconhecimento de $\mathrm{si}$ - da ideia do sujeito como efeitos no corpo: "sou" - não comparece no poema como pronome pessoal, mas como resultado do trabalho, da luta, do luto, da melancolia de perder a si mesmo e ter que voltar para buscar, assim nomeados: soar/suor/silenciar/descentrar. $\mathrm{O}$ ato de nomear, contudo, não determina os seres, e tampouco se restringe a descrevêlos e a descrever o espaço onde acontecem as coisas. A nomeaçáo age para relacionar corpo, espaço e linguagem. A sequência das açóes - quase inertes - encenam a formação da subjetividade. Nesse processo de dar existência ao "ser", não apenas pelo nome e sim pela relação de busca que os seres têm-consigo-mesmos e com o espaço, há uma conexão muito interessante com o pensamento desenvolvido por Aristóteles, no livro IV da Física. O 
filósofo clássico grego define, nesse texto, a "natureza” a partir da constatação do desenvolvimento de uma ação interior que é desencadeada a partir de uma "interioridade" que está relacionada ao espaço e ao movimento ${ }^{10}$. Em consequência disso, o pensamento selvagem também compreenderia uma ideia de natureza originada a partir de uma cena de um caos interno e náo de exterioridade. Uma ligação do pensamento aristotélico sobre a "natureza" (o mundo físico) pode ser observada no "naturalismo" da filosofia e da arte do século XVII - o Barroco. Em diferentes textos, a escrita de Josely opera a partir de uma ideia de mundo físico - "natureza" - concebido como uma ação interior desencadeada pela relação com o espaço e com o movimento. Aquilo que é nomeado como "natural" é, portanto, interior. A interioridade é entendida, nesse sentido, como uma cena do caos, em relação com espaço e movimento.

Em "sue", a construção sintática do poema movimenta-se desenvolvendo o mesmo percurso: a luta contra a secura produz o suor, portanto, a umidade que se buscava. A luta contra o sujeito idealizado, a partir de valores que lhe são exteriores, produz uma ideia de sujeito em devir. Trata-se de um desdobramento da concepção de natureza aristotélica que se replica no neobarroco latino-americano ${ }^{11}$.

\author{
sue \\ o secor do poço \\ soe \\ o oco do cepo \\ brote \\ o bulbo do fruto \\ vente \\ o pólen poente \\ (ventre)
}

(BAPTISTA, 2011, p. 133)

10 Para Aristóteles, no livro IV da Física, a mudança ou mutação estando relacionada ao tempo deve ser considerada como uma constante do movimento, não existindo por si própria: a mutação é relativa aos movimentos. O tempo é definido como "o número do movimento segundo o aspecto do antes e depois", por isso o tempo não pode existir sem uma sucessáo. Aristóteles, ao que parece, diz que a existência do tempo exige a presença de uma alma capaz de "contar" o movimento.

11 Debora Cota, em "Sobre barro, barroco e literatura ameríndia em roça barroca de Josely Vianna Baptista”, propóe, a partir da leitura do livro Roça Barroca, essa tese da relação entre o neobarroco latinoamericano e a pesquisa etnopoética realizada por Josely Vianna Baptista. Para Cota, o referido livro, dividido entre a traduçáo de alguns mitos guaranis e poemas de sua própria lavra, destaca o problema da gênese da escrita, da origem do pensamento e do próprio barroco como movimento e devir. Desse modo, o caráter etnopoético do trabalho da autora, o vínculo do mundo barroco colonial com a cultura ameríndia e a perspectiva neobarroca latino-americana "expóem constantes atualizaçóes que a conectam com as discussóes políticas/estéticas em torno da cultura ameríndia no Brasil contemporâneo". (COTA, 2019, p. 200). 
O poema dá a ver o nascimento do mundo/sujeito, sendo que as coisas passam a brotar no mesmo espaço onde já não existiam: "sue/ o secor do poço". O sujeito aparece mediado por reconhecimentos: o primeiro é o som oferecido pela montagem dos fonemas; o segundo é o constar que os lugares que eram, já não são: o poço seco, o cepo oco, o bulbo do fruto, $\mathrm{o}$ pólen caído. O poema acontece com a tarefa de fazer o mundo rebrotar: "o ventre". Tarefa realizada a partir de um terceiro reconhecimento: o caos e, portanto, é da morte que a natureza renasce.

No poema Fábula, incluído na página eletrônica do projeto $\mathrm{Na}$ tela rútila das pálpebras, é possível ler trechos daquele poema de Josely com Antunes. Da mesma forma que no poema-vídeo "Nada está fora do lugar", é possível ler novamente trechos de "Outro", acrescido dos versos do poema "sue", que funcionam como abertura do projeto:

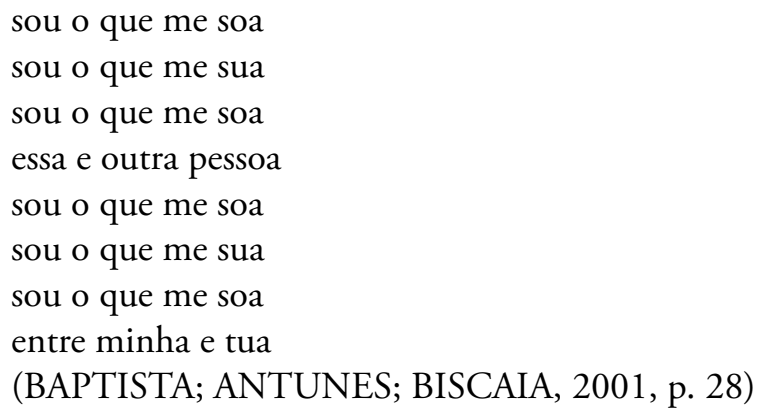

A esses versos são acrescentados os registros verbais do mito da terra sem males dos povos Guarani:

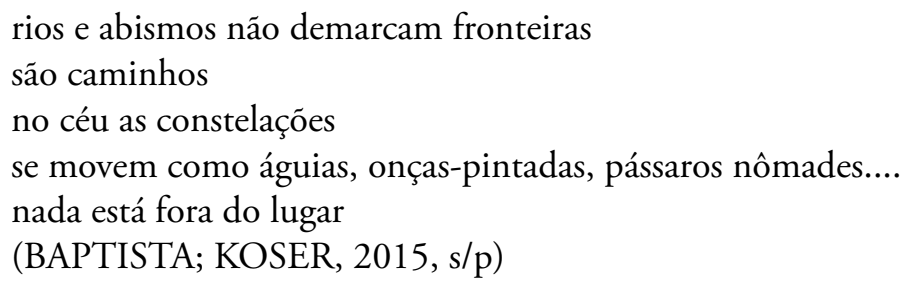

Esse "lugar" a que se refere o poema e a fala captada pela escuta do mito da terra sem males dos povos guarani não é compreendido como imagem/experiência da fronteira geopolítica. Ao contrário, ele é caminho para o conhecimento do que é simultaneamente estrangeiro e familiar nessa alteridade, e esse caminho se trilha a partir daquilo é mais íntimo: a relação com o espaço familiar, a natureza. Contudo, é esse íntimo também compreendido como o mais exterior. 
No Ocidente, o problema do pertencimento foi vinculado à ideia de que a língua materna era construída com a natureza local. Em decorrência disso, o espaço passou a ser tratado como "lugar discursivo", portanto, como "topologia do irreal", como já relembrou Giorgio Agamben quando tratou da incapacidade do discurso crítico de fazer referência àquilo que não é inapropriável.

Nessa perspectiva é que se pode falar de uma "topologia do irreal". Talvez o topos, essa coisa, segundo Aristóteles, "táo difícil de apreender", mas cujo poder "é maravilhoso e anterior a qualquer outro", e que Platão, no Timeu, concebe até mesmo como um "terceiro gênero" do ser, não é necessariamente algo "real" e, neste sentido, aqui se procurou levar a sério a pergunta que o

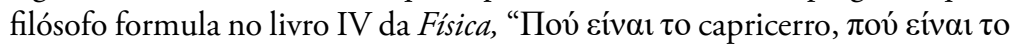

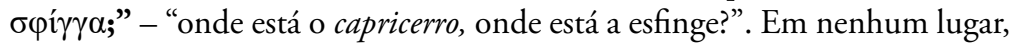
certamente, mas, talvez, porque eles mesmos sejam topoi. Ainda devemos habituar-nos a pensar o "lugar" não como algo espacial, mas como algo mais originário que o espaço; talvez, de acordo com a sugestão de Platão, como pura diferença, a que corresponde o poder de fazer com que "algo que náo é, de certa maneira seja, e aquilo que é, por sua vez, de algum modo não seja”.

[...]

Assim, a exploração topológica está constantemente orientada sob a luz da utopia. Se uma convicção sustenta tematicamente essa indagação no vazio em que a sua intenção crítica a obriga a ficar, é precisamente porque só se formos capazes de entrar em relação com a irrealidade e com o inapreensível como tais será possível apropriarmo-nos da realidade e do positivo.

(AGAMBEN, 2007, p. 15).

É interessante observar que os trabalhos de Josely Vianna e Lucrecia Martel referidos e analisados neste estudo compartilham um mesmo espaço geopolítico: o extremo oeste do planalto que cai na planície, o Chaco. Nesse espaço, experiência da escrita e da imagem transformam o ambiente natural, que passa a refletir os efeitos trágicos dessas experiências. $\mathrm{O}$ natural - a natureza exterior e o ser humano - são atravessados por uma sensação de antinatureza. Para se reconhecerem como "naturais" daquela geografia, necessitarão simbolizar e expurgar aquilo que está simplesmente dado. A anedota do peixe que, para sobreviver, tem que "fugir" do leito principal do rio e se instalar nas margens dá testemunho dessa experiência. A alegoria do peixe foi associada, nos poemas de Josely, à imagem do sujeito marcado pela experiência do suor e do soar para ser. Juntas dão testemunha da importância de uma atividade de mediação: daquela linguagem que redobra - simula e 
emula - à dos textos fundacionais da América Latina, fazendo a passagem do "topos" ao "utopos", passagem do "Dizer" ao "Ser", presente e ausente simultaneamente.

O processo de antinaturalização da natureza do Chaco, inclusive no seu aspecto humano e cultural, acontece nas imagens dos textos das duas autoras em questão. Trata-se de um expurgo e, com isso, criam em suas obras uma topologia do irreal. No filme, essa experiência é elaborada a partir das expectativas - quando se está diante de uma narrativa histórica - no que diz respeito a cenários e figurinos que nele, ao mesmo tempo, estão dequados e, sintomaticamente, fora de época. Os sons dos animais ouvidos durante as cenas parecem reproduções de gravaçóes feitas em estúdios, e não coletados no ambiente natural. As roupas e caracterização corporal dos atores têm ares futuristas com toques de minimalismo, ao contrário do que a historiografia teleológica do Barroco latino-americano requereria. Uma das imagensexperiência desse lugar-não-lugar discursivo ocupado pela natureza/ambiente é construída pela artificialidade da sonoplastia de ambos os filmes. No caso de Zama, os sons do ambiente parecem ter saído de gravadores eletrônicos. No poema-vídeo de Josely, a sobreposiçâo de fotogramas a imagens do espaço geográfico, mais os ruídos e as falas em diferentes línguas, "desrealizam" o ambiente indígena, transformando-o, ao lhe oferecer uma voz antinatural. Nesse sentido, os questionamentos produzidos pela linguagem empregada nesses trabalhos somente podem ser escritos por uma experiência aprés coup, nunca prévia, quiçá contemporânea, se o anacronismo - pensando como confluências de temporalidades - é seu fundamento. Toda experiência requer reelaboração histórica.

Zama de Lucrecia Martel redobra e expande o texto de Antonio Di Benedetto ao tornar mais complexo o discurso sobre a colonização. $\mathrm{O}$ foco narrativo que, no romance, é do protagonista, Don Diego de Zama, funcionário da justiça da Coroa Espanhola e corregedor para a planície/ depressão do Chaco paraguaio-argentino-boliviano-brasileiro, foi transferido para um elemento que, no livro de Di Benedetto, era um coadjuvante: a natureza. Lucrecia oferece à natureza um tratamento de ambiente, no qual se assiste a um tipo de movimento dialético - desdobrado nas cenas - em que os atores/personagens não são subsumidos em uma unidade absorvida pelo desenvolvimento absoluto da "História". A partir dessa dialética desdobrada e não teleológica, insiro o filme de Lucrecia e o poema-vídeo de Josely Vianna Baptista na prática de escritoras que assumem como tarefa a desconstrução de valores da modernidade masculina de conquista, dominaçáo e governança. Suas experiências com as histórias das culturas e das sociedades injetam na dualidade do movimento dialético um terceiro componente: lugar-nãolugarsemlugar, topos-utopos-atopos, familiar-estranho-esfinge, ao replicarem a 
função do protagonista/sujeito na natureza. Quando ela, a natureza, se transmuta para a função de ambiente que age, o Outro comparece na cena tornando-a complexa e retirando-a do ponto de vista unilateral da voz do Eu do humanismo ocidental, que é branca, masculina e europeia, redobrando a potência da "origem" na força do "caos" interior. Sáo muitos os seus pontos de confluência com a experiência latino-americana teorizada por Lezama Lima como "Barroco Americano", signo do "natural artifício" e da potência de "contraconquista". Tanto Lucrecia quanto Josely submetem o discurso do Eu à alteridade da natureza - o caos interior - e, com isso, cindem o discurso do antropocentrismo com um "contradiscurso", situado no lugar-não-lugarsemlugar latino-americano.

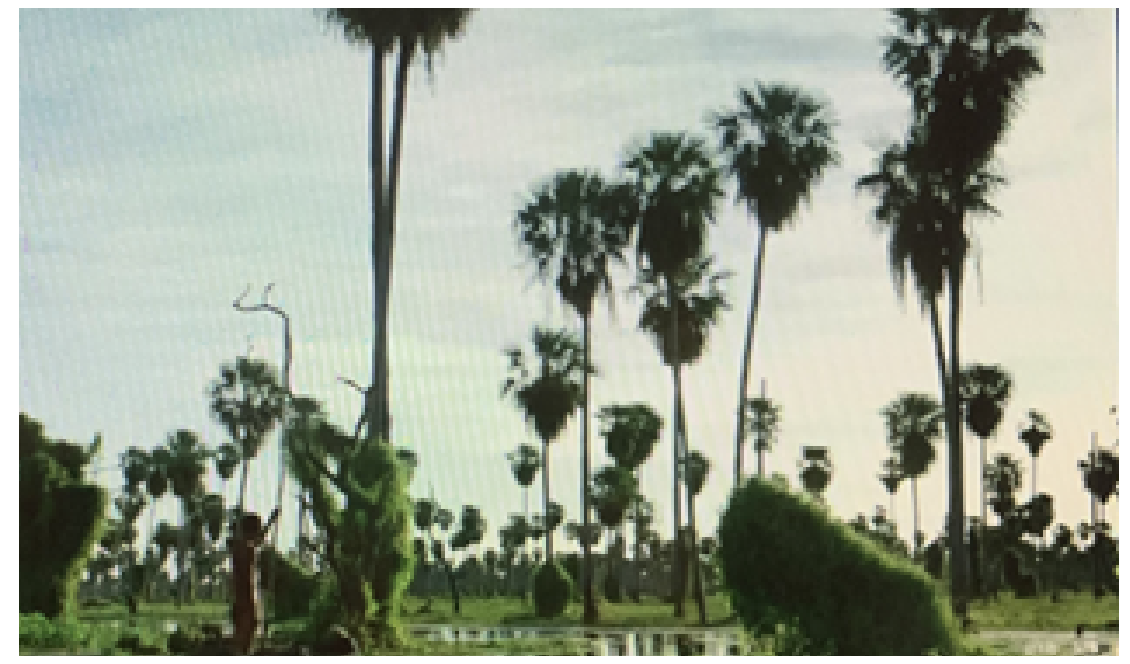

Figura 4 - Cena final de Zama

A cena final do filme de Lucrecia Martel (Figura 4) convoca ressonâncias tanto com a cena final do canto do "Inferno" na Comédia de Dante, quanto com o romance de Joseph Conrad. De Dante vem a imagem do barqueiro - nesse caso, o índio - que conduz o já quase morto protagonista com suas mãos decepadas da epopeia do inferno social da colônia para o coraçấo da selva. O coração da selva é também das trevas, onde há a "utopia" de poder ser o caminho para o paraíso ou para o inferno e, simultaneamente, para os dois lugares. A utopia é o motor desses trabalhos, pois tratam o espaço como negatividade, contudo, mantendo a possibilidade de ser: "sou o que me soa/ sou o que me sua", como dizem os versos do poema "Outro".

Este estudo se colocou na disposiçáo de pensar no contexto da literatura brasileira e latino-americana o problema do pertencimento daquilo que é 
inapropriável no âmbito da crítica literária e seu trânsito pela necessária e contingente reflexão sobre o espaço nacional e a língua materna. No mundo globalizado, essas mesmas questōes se desdobram em outras demandas na discussão por uma ética literária. O espaço geográfico não pode ser elaborado sem a linguagem que faz dele um lugar; e a língua materna não poderá ser articulada sem esses mesmos lugares aos quais lançará mão para existir. Nesse sentido, espaço geográfico e língua materna não preexistem, não são coisas que nascem como íntimas, já possuídas. São produto de um caos interior. Há que se oferecer sentido a elas como algo que diz respeito a muitos.

Diante disso, constatam-se as escolhas das obras estudadas neste ensaio: primeiro a do lugar: esse ponto de enunciação e arquivo; depois a do espaço: relativo à sua produçáo do interior e na relaçáo com ele; e finalmente da língua: essa maquinaria produtora de fetiches, que nunca tem de ser uma apenas, pois podem ser muitas, pertencentes simultaneamente a diferentes espaços geográficos e produtoras de diversidade, diferentes topoi. Escolher não tem o sentido de se perder alguma coisa, e sim de ampliar o que é mais caro a alguém. Tudo é topoi e, por isso, "nada está fora de lugar".

\section{Referências}

AGAMBEN, Giorgio. Estâncias. A palavra e o fantasma na cultura ocidental. Tradução Selvino Assmann. Belo Horizonte: Ed. UFMG, 2007.

ARISTÓTELES. Física. Introducción, traducción y notas. Guillermo R. de Echandía. Madrid: Editorial Gredos, 1995.

BAPTISTA, Josely Vianna. Fábula. NADA ESTÁ FORA DO LUGAR. Poema arborescente. São Paulo: Demônio Negro, 2017.

. Nada está fora do lugar. Poema-vídeo. Criação coletiva de Josely Vianna Baptista, Yasmin Thayná, Waltel Branco, Guillermo Sequera e Francisco Faria (2017). Disponível em: https://www.youtube.com/watch?v=otugkzpyghi\&vl=pt . Roça barroca. São Paulo: Cosac Naify. 2011.

BAPTISTA, Josely Vianna; KOSER, José. Na tela rútila das pálpebras. 2015. Disponível em http://natelarutiladaspalpebras.telarutila.com/na-tela-rutila-(p).html

BAPTISTA, Josely Vianna; ANTUNES Arnaldo, BISCAIA, Maria Angela. Outro. Curitiba: Mirabilia, 2001.

BENJAMIN, Walter. Origem do drama barroco alemão. Trad. Sergio Rouanet. São Paulo: Brasiliense, 1984. 
BENJAMIN, Walter. Dois poemas de Friedrich Hölderlin. In: Escritos sobre mito e linguagem. Trad. Susana Kampff Lages e Ernani Chaves. São Paulo: Duas Cidades, 2011, p. 13-19.

COTA, Débora. Sobre barro, barroco e literatura ameríndia em roça barroca de Josely Vianna Baptista. Revista Humanidades \& Inovação, v. 6, n. 5, p. 199-206, 2019.

DI BENEDETTO, Antonio. Zama. Buenos Aires: Adriana Hidalgo. 2018. . Zama. Tradução Ester Allen. Rio de janeiro: Ed. Globo. 2006.

LIMA, Lezama. La expresión americana. México, D.F.: Fondo de Cultura Económico. 1993.

MARTEL, Lucrecia. Zama. Baseado no romance de Antonio Di Benedetto. Produção Rei Cine e Bananeira Filmes. Argentina, Brasil, Espanha, França, México, USA, Netherlands, Portugal. 2017.

PEDROSA, Celia. Josely Vianna Baptista: uma poética xamânica da tradução e da tradição. Alea, Rio de Janeiro, v. 20, n. 2, p. 92-104, 2018.

SCRAMIM, Susana. A metáfora. Um lugar mais originário que o espaço. In: Literatura do presente. História e anacronismos dos textos. Chapecó: Ed. Argos, 2007.

SCRAMIM, Susana. Infância, arquivo e experiência. In: Literatura do presente. História e anacronismos dos textos. Chapecó: Ed. Argos, 2007.

Susana Scramim é professora Titular de Teoria Literária na Universidade Federal de Santa Catarina e pesquisadora produtividade do Conselho Nacional de Desenvolvimento Científico e Tecnológico (CNPq). Membro do Comitê Assessor da Área de Letras e Linguística no CNPq (2018-2021). Tem experiência na área de Letras, com ênfase em Teoria Literária, Ensino de Literatura, Literatura Brasileira e Literatura Comparada. Entre suas principais publicaçóes estão os livros: Literatura do Presente (Ed. Argos, 2007); Carlito Azevedo, Ciranda de Poesia (EDUERJ, 2010); "Pervivências" do arcaico: a poesia de Drummond, Murilo Mendes e Cabral e sua sombra (Editora 7Letras, 2019).

E-mail: sscramim@uol.com.br 